\title{
Characterization of forest carbon stocks at the landscape scale in the Argentine Dry Chaco
}

\author{
Priscila Ana Powell ${ }^{\mathrm{a}, \mathrm{b}, *}$, Ana Sofía Nanni ${ }^{\mathrm{a}}$, María Gabriela Názaro ${ }^{\mathrm{a}}$, Dante Loto ${ }^{\mathrm{c}}$, Ricardo Torres ${ }^{\mathrm{d}}$, \\ Néstor Ignacio Gasparri ${ }^{\mathrm{a}, \mathrm{e}}$ \\ ${ }^{a}$ Instituto de Ecología Regional, CONICET \& Universidad Nacional de Tucumán, CC 34 Yerba Buena, 4107 Tucumán, Argentina \\ b Cátedra de Ecología General, Facultad de Ciencias Naturales e IML, UNT. Miguel Lillo 205, San Miguel de Tucumán, Argentina \\ ${ }^{\mathrm{c}}$ Instituto de Silvicultura y Manejo de Bosques, CITSE-UNSE, Av. Belgrano (S) 1912, Santiago del Estero, Argentina \\ d Instituto de Diversidad y Ecología Animal (IDEA - CONICET), y Museo de Zoología, Facultad de Ciencias Exactas, Físicas y Naturales, UNC, Av. Vélez Sarsfield 299, \\ X5000JJC Córdoba, Argentina \\ e Cátedra de Ecología del Paisaje, Facultad de Ciencias Naturales e IML, UNT, Miguel Lillo 205, San Miguel de Tucumán, Argentina
}

\section{A R T I C L E I N F O}

\section{Keywords:}

Forest carbon

Wood density

Net primary production

Subtropical dry forest

Carbon attributes, Argentina

\begin{abstract}
A B S T R A C T
One of the most proposed climate change mitigation strategies is carbon sequestration by vegetation. This depends on the rate of carbon uptake and transformation in biomass, the rate of release through respiration, and the stability of the stocks to disturbances. Forest diversity influences these factors, in a degree that varies according to certain functional characteristics. The Dry Chaco is the largest dry forest in the world, and one of the regions with the highest deforestation rates of the planet. Our aim was to geographically describe three carbon stock attributes from forest communities of the Dry Chaco Forests in Argentina at the landscape scale: wood density, tree height and annual carbon increase in aboveground biomass, as proxies of forest stability and carbon long-term persistence. In addition, we evaluated the relationships between these attributes and climate features, in the search of potential climate controls. Higher precipitation during the growing season and low mean annual temperature benefited the combination of these three treats related to $\mathrm{C}$ storage persistence. The distribution of the most favorable states of the three attributes is centered at the northwestern area of the Dry Chaco. Our geographic description of carbon stocks attributes can contribute to more suitable conservation planning and allows forecasting potential shifts in forests due to climate change.
\end{abstract}

\section{Introduction}

The role of forests in the global and regional carbon cycles, and their importance as carbon sinks have been largely acknowledged, especially in contexts of increasing carbon emissions (Houghton, 2007). Further, the understanding of biomass spatial patterns and biomass stocks in different forest types, and in relation to biophysical traits and land use has improved through the development of local and global AGB spatial explicit models in many regions of the world (e.g. Dahlin et al., 2012; Gasparri and Baldi, 2013; Saatchi et al., 2011). Nevertheless, one of the main caveats of these models is that they represent only the amount of carbon stored, which is in itself the result of the interaction of forest species functional traits such as wood density, canopy height, and vegetation growth (Chave et al., 2006; Simard et al., 2011; Zhao et al., 2006). While all the mentioned aspects are usually predictive parameters in AGB estimations (Chave et al., 2005; Zhao et al., 2006), they are also indicators of other characteristics of the tree community that are relevant in terms of their ecology. These characteristics of trees at the ecosystem level are important to determine the attributes of forests and the stability of carbon stocks, or the velocity of carbon capture, beyond or in addition to the particular AGB value.

Functional diversity of woody species plays an important role in determining forest carbon stock (Conti and Díaz, 2013; Díaz et al., 2009) affecting its potential accumulation and stability. Through a local scale analysis for the Chaco ecoregion, Conti and Díaz (2013) found that community-weighted-mean of wood density and height were the only functional traits acting as predictor variables of carbon plant storage. Wood density is a good indicator of the turnover rate of AGB stocks, with fast-growing species usually exhibiting lower wood density in comparison to slower-growing species of later successional stages (Muller-Landau, 2004; Rowe and Speck, 2005). High wood density is more expensive to build, implying slow growth, but also confers more resistance to drought stress and to physical damage, pathogens, and predators than low density wood species (Hacke et al., 2001; Meinzer,

\footnotetext{
* Corresponding author at: Instituto de Ecología Regional, CONICET \& Universidad Nacional de Tucumán, CC 34 Yerba Buena, 4107 Tucumán, Argentina

E-mail address: priscilaapowell@gmail.com (P.A. Powell).
} 
2003; Rowe and Speck, 2005). Thus, longevity is a proxy of long- term persistence, both of which ultimately lead to more stable carbon stocks through time (Díaz et al., 2009). Woodland vertical structure is also a good predictor of aboveground live biomass (Chave et al., 2005; Lefsky et al., 2002), primary productivity and, in some cases, biodiversity. For a long time, forestry science has used the dominant height as an indicator of site quality and production potential (Oliver and Larson, 1996) Indeed, due to the availability of Glas Lidar tree height estimations at the global scale, Saatchi et al. (2011) estimated total AGB for tropical regions of the world. Net primary production (NPP) represents the rate of carbon input in terrestrial ecosystems (Cao and Woodward, 1998), and directly impacts over AGB (Clark et al., 2001), carbon stock increase, and turnover. But both the annual values of net primary production, and the proportion allocated in the form of AGB vary largely, seasonally and spatially, and dependently on the dominant plant communities. In addition, they are highly correlated with environmental factors, such as precipitation, especially in the tropics and at intermediate latitudes (Cao and Woodward, 1998; Houghton et al., 2012; Pan et al., 2011).

As seen, functional attributes can influence carbon stocks, yet estimations at the landscape scale are mainly centered on the quantification of the amount of carbon stored on AGB, without taking into account other relevant dimensions of carbon sequestration, including aspects of forest functional diversity related to stability and time to capture carbon (Díaz et al., 2009).

The resulting composition of vegetation in a given area is the product of strong feedbacks between environmental features and anthropogenic activities (Xie et al., 2008), the former also determining species functional traits. In dry forests, one strong environmental feature shaping vegetation characteristics is regular water deficit, which derives in multiple plant community adaptations to stressed environmental conditions (Kunst et al., 2012). Tree communities in dry forests generally exhibit lower net primary productivity (NPP), lower tree height and slower successional rates, deriving in lower AGB values and higher wood density in comparison to moist forests (Chave et al., 2006), and larger time and energy requirements to reach them (i.e., higher "building costs"). Also, slower carbon turnover implies more carbon stability and longevity, both of them important features in terms of long-term climate regulation by ecosystems (Díaz et al., 2009). Due to the strict focus in AGB values, such features have been overlooked. Complementing AGB estimations with the characterization of carbon stock attributes at regional scales could help designing perdurable mitigation efforts, which take into account both the amount of accumulated carbon, the resilience of the system, and the "costs" of nature to build them.

The aim of this study is to define types of carbon stocks in the Argentine Dry Chaco at a landscape scale. To achieve that, we studied the geographic patterns of three ecosystem attributes that affect carbon stocks in forests of the Argentine Dry Chaco, and their climatic controls, using available regional data. Specifically, we describe geographic patterns of: 1-forest wood density at the community level, using tree species distribution models, 2-canopy heights, using LIDAR estimations, and 3-carbon sequestration rate (in AGB per year), using MODIS estimations of net primary production. We then analyze their association with climatic data.

\section{Materials and methods}

\subsection{Study area}

The Dry Chaco ecoregion is an extensive sedimentary plain, originated by fluvial activity. It covers 1.2 million $\mathrm{km}^{2}$ (Dinerstein et al., 1995), along western Paraguay, southeastern Bolivia and northern Argentina. In the latter (Fig. 1), it includes $420.000 \mathrm{~km}^{2}$ of xerophytic forests and grasslands, with the canopy represented mainly by the genera Aspidosperma, Schinopsis and Bulnesia, which reach 16-18 m tall.
Below this stratum, dominant genera are Acacia, Prosopis, Capparis, Celtis, Opuntia and Sarcomphalus. Grasslands are represented by Elionurus, Pappophorum and Heteropogon genera (Kunst, 2011; Morello and Rodriguez, 2009; Torrella and Adámoli, 2005). Annual mean temperatures are between 19 and $24^{\circ} \mathrm{C}$, with occasional extreme high temperatures above $40^{\circ} \mathrm{C}$. The rainfall regime is monsoonal, with annual precipitation mostly concentrated in summer (December-toMarch). The eastern sector is more humid, with about $1000 \mathrm{~mm} /$ year, and decreases towards the west, with less than $450 \mathrm{~mm} /$ year (Sarmiento, 1972).

The Chaco preserves the second largest forested ecosystem after the Amazon (Portillo-Quintero and Sánchez-Azofeifa, 2010), but it has been heavily affected by deforestation and land use intensification in the last decades (Baumann and Gasparri, 2016; Hansen et al., 2013). In Argentina, this has occurred mainly due to the expansion of soybean, maize and wheat, especially after the introduction of genetically modified soybean variants due to rising global crop prices during the $2000 \mathrm{~s}$ (Gasparri et al., 2013). These trends originated high and accelerated rates of deforestation (Baumann and Gasparri, 2016), with significant impacts on carbon regional balances (Gasparri et al., 2008), that enhance the need of carbon fluxes and stocks assessments. Maps of aboveground carbon for the Argentine Dry Chaco have been developed through the combination of remote sensing and field sampling, and revealed variability in aboveground biomass, proposed to be controlled mainly by climate (especially temperature of the coldest months) but also by land use history effects (Gasparri and Baldi, 2013).

\subsection{Forest carbon attributes}

To geographically characterize the carbon stock attributes of the Dry Chaco forests, we estimated weighted mean wood density, tree canopy height and carbon sequestration rate (in AGB per year), using satellite products and tree species distribution models of the Dry Chaco. We performed all calculations using R software (R Core Team, 2015), and all maps using Q gis software (2017).

We derived tree canopy heights from an existent map of forest canopy height (in meters) at $1 \mathrm{~km}$ spatial resolution, built by Simard et al. (2011), with 2005 data from the Geoscience Laser Altimeter System (GLAS) aboard ICESat System (GLAS). This map (that excludes nonforest covers) was also used as a woodland mask for all the raster data, to exclude other land cover types. The minimum height of canopy considered was $6 \mathrm{~m}$.

To estimate weighted mean wood density from trees of the Dry Chaco ecoregion per pixel, we combined habitat suitability models of native tree species with wood density values per specie from INTICITEMA database (INTI-CITEMA, 2003). We then estimated the weighted mean wood density $\left(\mathrm{g} / \mathrm{cm}^{3}\right)$, averaged by habitat suitability per pixel (see below) for each species, using R software (R Core Team, 2015). Finally, we obtained a map that represents the estimated weighted mean wood density of trees for each pixel.

We fitted habitat suitability models with presence data of 23 native tree species and biophysical variables (climate, soil and topographic features), with a spatial resolution of $1 \mathrm{~km}$, modifying the methods used by Torres et al. (2014). We fitted suitability models with Maxent v3.3 (Phillips et al., 2006), which implements a maximum entropy algorithm to obtain suitability surfaces based in environmental features at occurrence localities. Maxent is a widely used method for fitting habitat suitability models, although it is not exempt of criticisms. We followed the recommendations in Merow et al. (2013) and Yackulic et al. (2013). We obtained, for each species, the habitat suitability per pixel as a continuum value ranging from 0 (lowest suitability) to 1 (highest suitability). We selected the 23 tree species based on their representativeness in the Chaco forests, and the availability of occurrence localities (further detail in SI, including methods, species list and wood density values).

For estimating forest carbon sequestration rate, we used the MODIS 


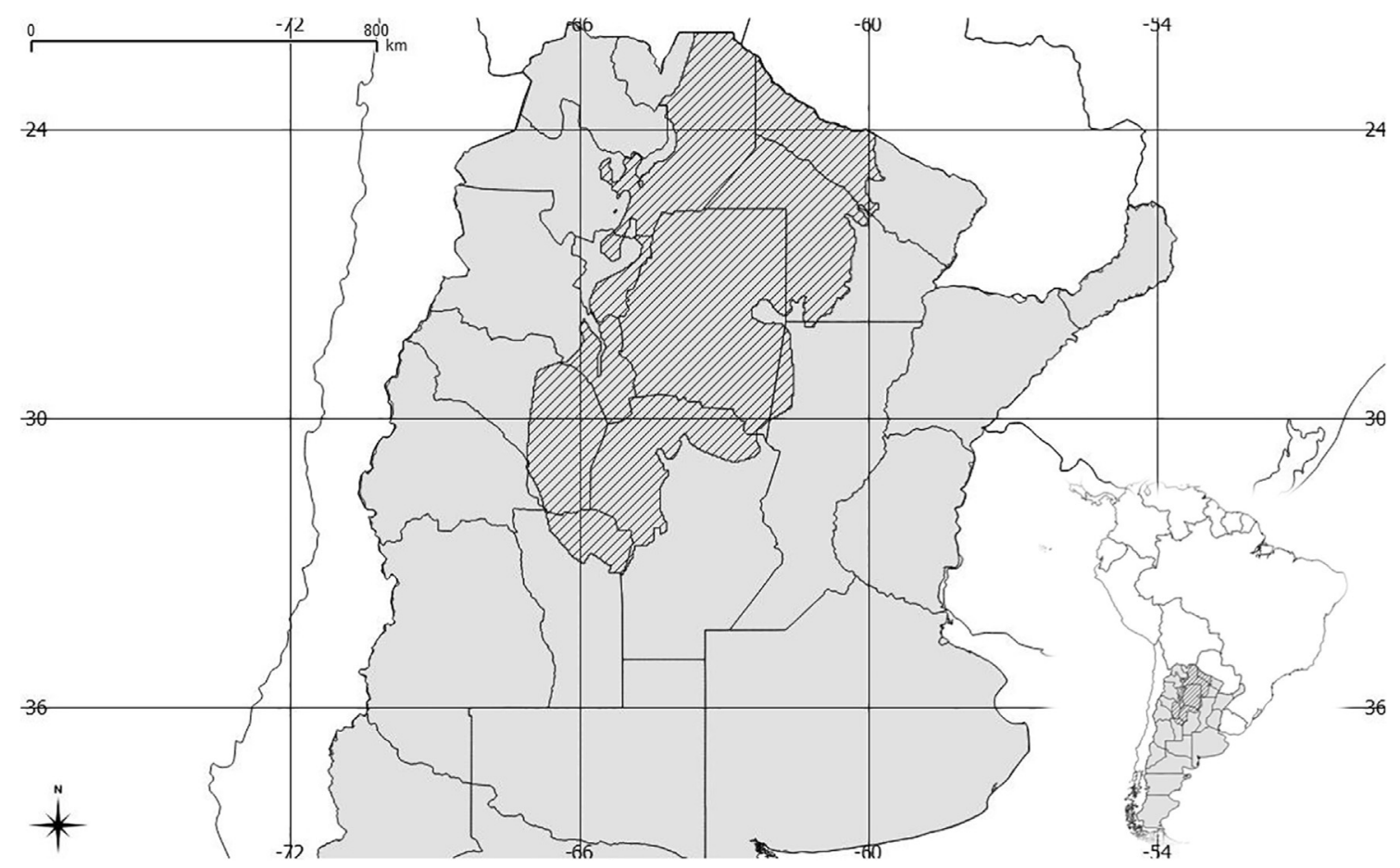

Fig. 1. Study area. Stripped area indicates Dry Chaco extension in Argentina. Small inset shows the location of Argentina (in grey) within South America.

MOD17A3 product, which provides annual continuous estimates of NPP from 2000 to 2014. This product represents the difference between the rate at which plants in an ecosystem produce useful chemical energy (or GPP), and the rate at which they spend part of that energy for respiration (Zhao et al., 2006). The NPP value at a given pixel and at a given year is thus the carbon accumulated by growth in that year. To avoid potential biases due to specific climate conditions associated to a particular year (e.g. droughts, wet periods), we estimated the average NPP values for each pixel, including information from 2000 to 2014 . For a clearer idea of the meaning of that quantity in terms of carbon stocks, we transformed the averaged NPP per pixel in the amount of carbon accumulated in the form of AGB in one year, using an average of the proportion of NPP converted in AGB for tropical dry forests from Clark et al. (2001). Specifically, and based on such calculation, we multiplied each pixel of NPP by 0.3 , to then transform the units to MgC/ ha.

\subsection{Classification of forest carbon stock typologies}

For an approximation of distinctive forest typologies based on the carbon stock attributes described above, we classified each attribute in two classes: more favorable or less favorable with respect to carbon accumulation. The following aspects were considered positive when their values exceeded our estimated mean values for the ecoregion, and thus assigned arbitrary numeric values to each pixel to identify the distinctive existing combinations (Table 1): high weighted mean wood densities, fast carbon accumulation, and high canopy heights. Each pixel was reclassified using the arithmetic mean value. All "less favorable" states (i.e., values below mean values) of each attribute were reclassified with a 0 value. Then, we summed these new three maps (corresponding to each carbon attribute) to obtain the different carbon stock typologies per pixel, where: 0 , corresponds to "less favorable pixels in terms of carbon accumulation" (i.e., none of the attributes are favorable); while more favorable integers correspond to different combinations of more and less favorable attributes $(1,3,4,5,6,8$ and 9) in which: 9 represents "the most favorable" areas in terms of carbon accumulation, 4, 6 and 8 represent "intermediate favorable areas" (at least two attributes classified as more favorable) and 1, 3 and 5 are sites
Table 1

Maximum, mean, minimum and standard deviation for the three analyzed carbon stock attributes at the tree community level.

\begin{tabular}{lllll}
\hline Carbon stock attribute & Maximum & Mean & Minimum & $\begin{array}{l}\text { Standard } \\
\text { deviation }\end{array}$ \\
\hline $\begin{array}{c}\text { Tree canopy height (m) } \\
\begin{array}{c}\text { Weighted mean wood density at } \\
\text { the community level (g/ } \\
\mathrm{cm}^{3} \text { ) }\end{array}\end{array}$ & 0.83 & 0.76 & 0.73 & 0.02 \\
$\begin{array}{c}\text { Amount of carbon accumulated } \\
\text { in AGB per year (MgC/ha) }\end{array}$ & 21.4 & 1.56 & 0.0003 & 1.42 \\
\hline
\end{tabular}

with only one more favorable attribute. With the final classification map, we used the focal analysis function to erase isolated pixels.

After the classification, we made a visual interpretation of potential causes of such combination of attributes, using Google Earth images, bibliography, and expert knowledge.

\subsection{Associations between carbon stock attributes and environmental features}

To evaluate the influence of environmental variables on each carbon stock attribute, we performed linear regressions using bioclimatic variables as independent variables (19 variables of the Chelsa database (Karger et al., 2017), and the De Martonne Aridity index (de Martonne, 1926), as an indicator of pixel dryness. To estimate the performance of the models, we used the Akaike information Criterion (AIC, Akaike, 1987), choosing the model with the lowest AIC value. All analyses were performed in R software (R Development Core Team, 2015).

Although the habitat suitability for each species was modeled according to climate variables with the Chelsa database (Karger et al., 2017), we believe that weighted mean wood density can be considered as a new attribute, since it results of combining the wood densities of 23 species which differentially respond to climate variables. This validates the analysis between weighted mean wood density and climate. 

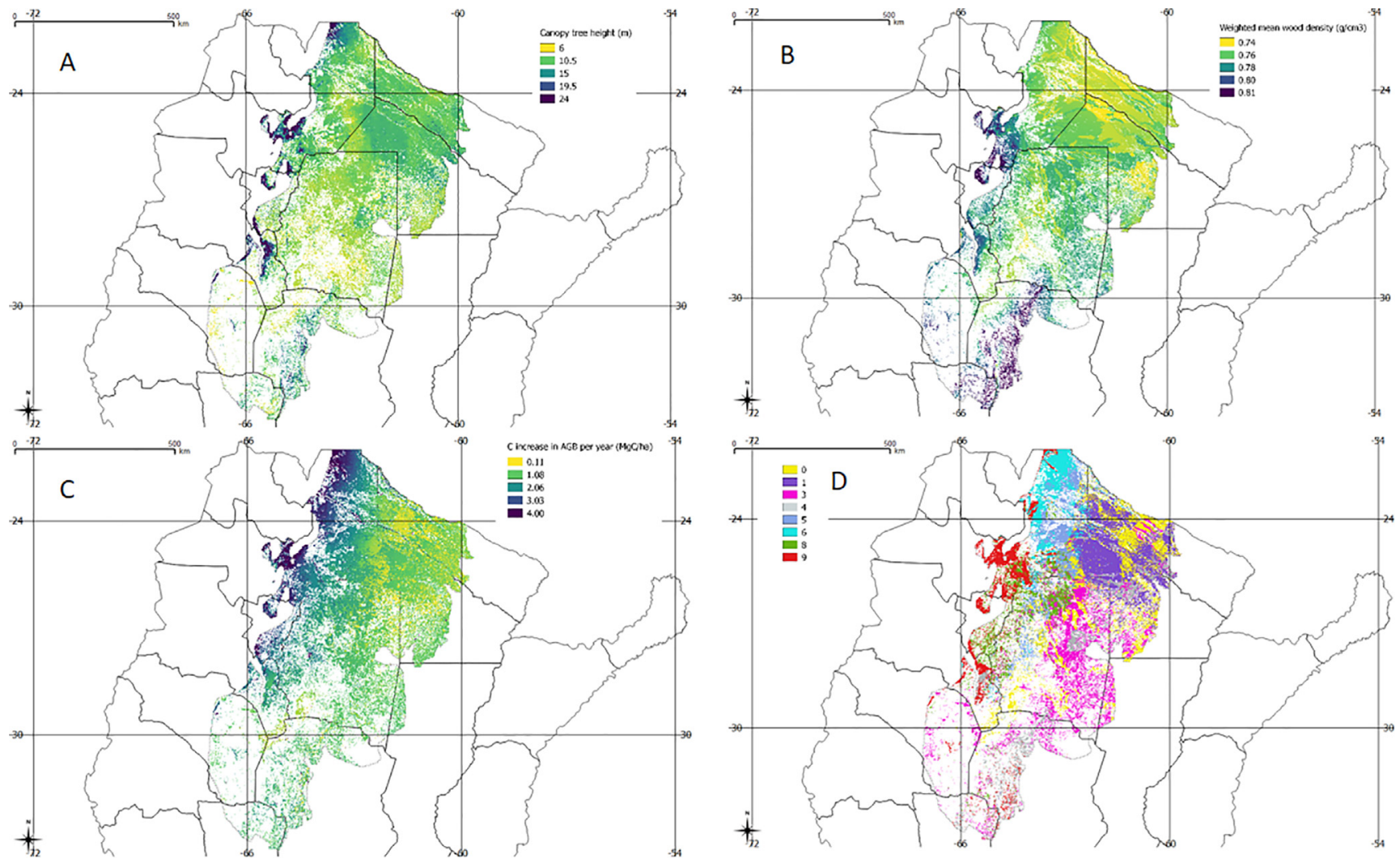

Fig. 2. Geographic patterns of the three community attributes that affect the potential carbon stock in forests of the Argentine Dry Chaco. A-Canopy height (in m). Bweighted mean wood density at the community level $\left(\mathrm{g} / \mathrm{cm}^{3}\right)$. C-carbon sequestration rate $(\mathrm{MgC} / \mathrm{ha})$. D-Carbon stock typologies. 0: low Wood density, low tree canopy height, slow growth; 1: low Wood density, high tree canopy height, slow growth; 3: high Wood density, low tree canopy height, slow growth; 5: low Wood density, low tree canopy height, fast growth; 4: high Wood density, high tree canopy height, slow growth; 6: low Wood density, high tree canopy height, fast growth; 8: high Wood density, low tree canopy height, fast growth; 9: high Wood density, high tree canopy height, fast growth.

\section{Results}

\subsection{Carbon stock attributes}

The values for canopy height, weighted mean wood density, and carbon increase in AGB are presented on Fig. 2, and basic statistics for each attribute are available in Table 2. Most of the high values of tree carbon attributes are concentrated in the northwestern area of the ecoregion, while less favorable sites are mainly towards eastern and central areas (Fig. 2D). We found all the possible combinations of three carbon stock attributes in Argentine Dry Chaco, but their distribution was not homogeneous. Almost half of the Chaco ecoregion (about $46.4 \%$ ), presented only one favorable state of a given carbon attribute (Fig. 2D, Table 2), mainly corresponding to high weighted mean wood density, or high tree canopy heights. Most of the areas with no

Table 2

Classification of the carbon stock community attributes for Chaco pixels.

\begin{tabular}{lll}
\hline Attribute status & Score & $\begin{array}{l}\text { Percentage of area } \\
\text { represented (\%) }\end{array}$ \\
\hline $\begin{array}{l}\text { Less favorable status in terms of carbon } \\
\text { accumulation (i.e., none of the attributes are }\end{array}$ & 0 & 16.91 \\
$\quad$ favorable) & 1 & \\
High canopy heights & 3 & 18.98 \\
High wood densities & 5 & 9.03 \\
Fast carbon accumulation & 4 & 10.95 \\
High canopy heights + high wood densities & 6 & 8.02 \\
High canopy heights + fast carbon accumulation & 8.33 \\
High wood densities + fast carbon accumulation & 8 & 9.39 \\
High wood densities + fast carbon & 9 & \\
$\quad$ accumulation + high canopy heights & & \\
\hline
\end{tabular}

favorable state of carbon stock accumulation were located in the northeast and center of the ecoregion, corresponding to flooded areas, savannahs and cultivated areas. One third of the area presented the different possible combinations of two positive states of carbon attributes, and nearly $10 \%$ of the surface exhibited fast carbon accumulation, high canopy tree height and high weighted mean wood densities. These three attributes concentrating towards the west, limiting with the Yungas ecoregion.

\subsection{Associations between carbon stock attributes and bioclimatic variables}

We found positive linear associations between carbon attributes (Fig. 3). Tree canopy height was higher in pixels with higher weighted mean wood density (Fig. 3A), and also in pixels with higher AGB increase (Fig. 3B). Consequently, pixels with larger amount of carbon accumulated in AGB exhibited higher weighted mean wood density (Fig. 3C).

A subset of all possible models tested for each carbon stock attribute are shown on Table 3. Canopy tree height is positively controlled by the precipitations of the wettest season, and negatively controlled by mean annual temperatures (Table 3, Fig. 4A and B). Weighted mean wood density is better explained by a quadratic model using maximum temperatures: wood densities increase until $25^{\circ} \mathrm{C}$, to then decrease with increasing maximum temperatures. Precipitations during the wettest season is the most relevant climatic factor to explain carbon increment in AGB (Table 3, Fig. 4D).

\section{Discussion}

In this study, we spatially characterized three carbon stock 

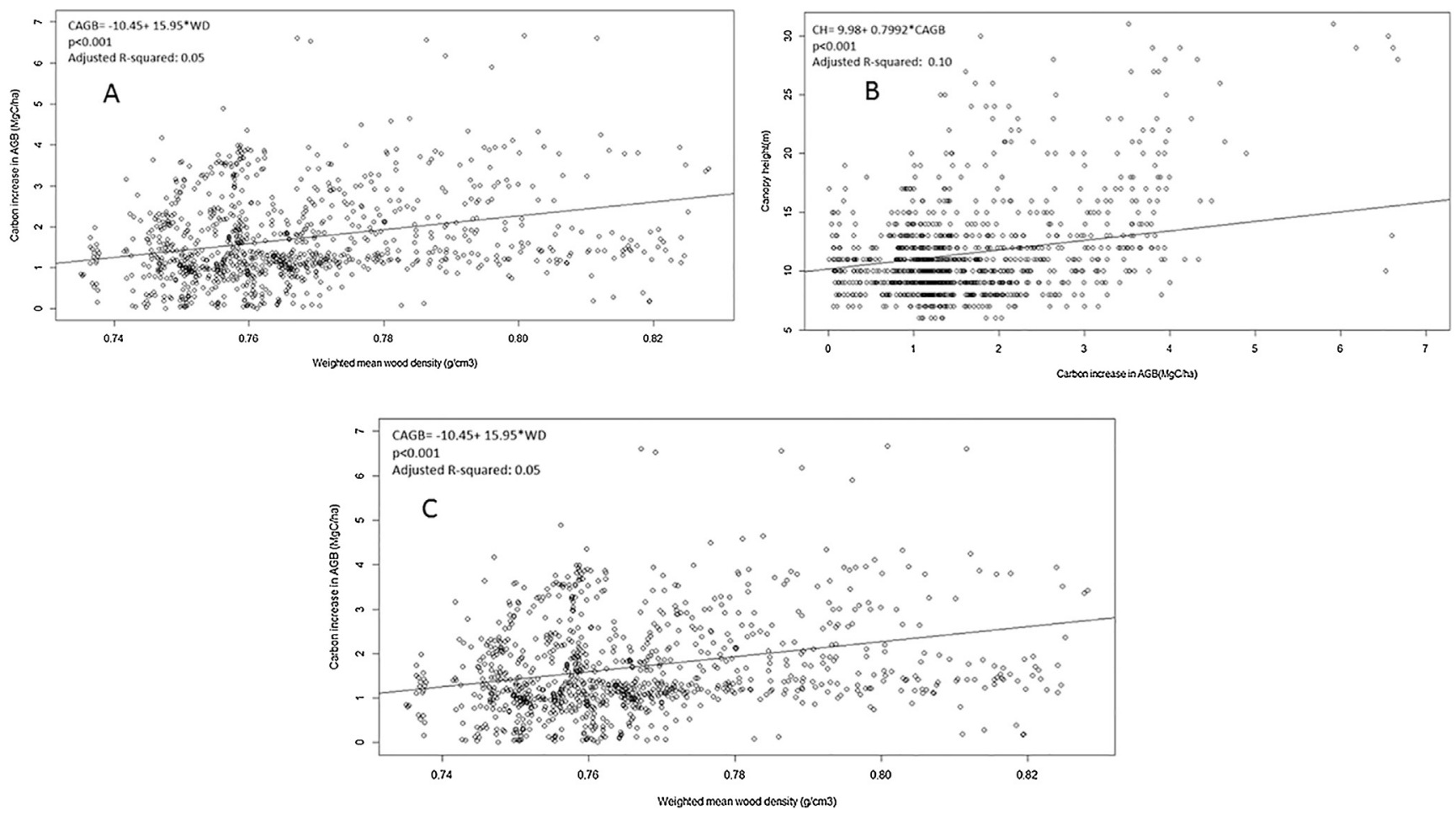

Fig. 3. Associations between carbon stock attributes. The model equation, p-value and adjusted R-squared are presented at the left corner of each scatterplot. $\mathrm{CH}=$ canopy height, $\mathrm{WD}=$ weighted mean wood density, $\mathrm{CAGB}=$ carbon increase in AGB. 4A: Canopy tree height $(\mathrm{m}) \mathrm{vs}$ weighted mean wood density $\left(\mathrm{g} / \mathrm{cm}^{3}\right) ; 4 \mathrm{~B}$ : Canopy tree height vs Carbon increase in AGB (MgC/ha); 4C: Carbon increase in AGB $(\mathrm{MgC} / \mathrm{ha})$ vs weighted mean wood density $\left(\mathrm{g} / \mathrm{cm}^{3}\right)$.

attributes in the Dry Chaco ecoregion of Argentina, which exert a great influence over certain features of forests, such as carbon sequestration capacity, turnover rate, and vulnerability under disturbs (Díaz et al., 2009). Although these community attributes are positively related, and therefore share certain environmental controls, they are not always found together in the study area. Since they are informative of the carbon sequestration potential in the long-term, these attributes can provide insights to guide long-term carbon conservation efforts in dry forests (e.g., in regions where the three attributes are combined), beyond or in addition to the strict focus on aboveground biomass values.

The values of weighted mean wood density at the landscape level found, especially high towards the west and south of the Argentine Dry Chaco, were higher than the mean wood density values reported by Chave et al. (2006) for the Neotropics at the landscape level. One reason might be that the Dry Chaco ecoregion is characterized by the presence of several species with hard woods (i.e., high wood density), such as Aspidosperma quebracho-blanco, Bulnesia sarmientoi, Prosopis kuntzei and Schinopsis lorentzii (Torella and Adámoli, 2005), that compos chacoan canopies. Also, certain shorter tree species, such as
Celtis tala, Geoffroea decorticans and Sarcomphalus mistol, and even other early successional trees have higher wood densities than the mean estimated by Chave et al. (2006). Due to the presence of species with hard woods, some of them have been intensively extracted, especially during the XIX century (Morello et al., 2005). Further, high wood density is an adaptation to drought stress (Hacke et al., 2001). Thus, high levels of wood density are associated with higher tree survival and resistance to damage, lower tree mortality, and generally, unpalatable leaves (King et al., 2006; Chao et al., 2008). This attribute could therefore imply the existence of carbon stocks that are more perdurable, and less vulnerable to disturbances. Also, and due to their resistance to predators, pathogens, physical damage (Rowe and Speck, 2005) and droughts (Carlquist, 1977), higher wood densities can bring more opportunities for the development of higher trees, explaining the positive associations among the two attributes. In the Argentine Chaco, tree height is frequently excluded from AGB estimations (Gasparri and Baldi, 2013), with the consequent introduction of a systematic error (Chave et al., 2005; Feldpausch et al., 2010; Nogueira et al., 2011). This is due to the fact that the close canopy of the Chaco forests obstruct the

Table 3

Parameter estimates, AIC values and $\triangle$ AIC for a subset of analyzed models.

\begin{tabular}{|c|c|c|c|c|c|c|}
\hline \multirow[t]{5}{*}{ Canopy tree height } & Model & Intercept & Coefficient parameter1 & Coefficient parameter2 & AIC & $\Delta \mathrm{AIC}$ \\
\hline & Null & 11.47 & - & - & 5847.1 & 283.3 \\
\hline & Annual mean temperature & 25.28 & -0.67 & - & 5660.4 & 96.6 \\
\hline & Precipitation of wettest period + annual mean temperature & 17.40 & 0.04 & -0.58 & 5563.8 & 0.0 \\
\hline & Martonne index & 7.08 & 0.17 & - & 5789.8 & 226.0 \\
\hline \multirow[t]{4}{*}{ Weighted mean wood density } & Null & 0.77 & - & - & -4981.0 & 1560.8 \\
\hline & Mean temperature (quadratic model) & 0.71 & 0.01 & 0.00 & -6346.0 & 196.2 \\
\hline & Max temperature of warmest month (quadratic model) & 0.35 & 0.04 & -0.001 & -6542.0 & 0.0 \\
\hline & Max temperature + Precipitation of wettest period & 0.93 & -0.01 & 0.0001 & -5863.0 & 678.8 \\
\hline \multirow[t]{4}{*}{ Carbon increase in AGB } & Null & 1.71 & - & - & 3664.0 & 69.0 \\
\hline & Mean temperature & 3.16 & -0.07 & - & 3651.0 & 56.0 \\
\hline & Max temperature of warmest month & 5.73 & -0.13 & - & 3622 & 27.0 \\
\hline & Precipitation of wettest season & 0.30 & 0.01 & - & 3595.0 & 0.0 \\
\hline
\end{tabular}



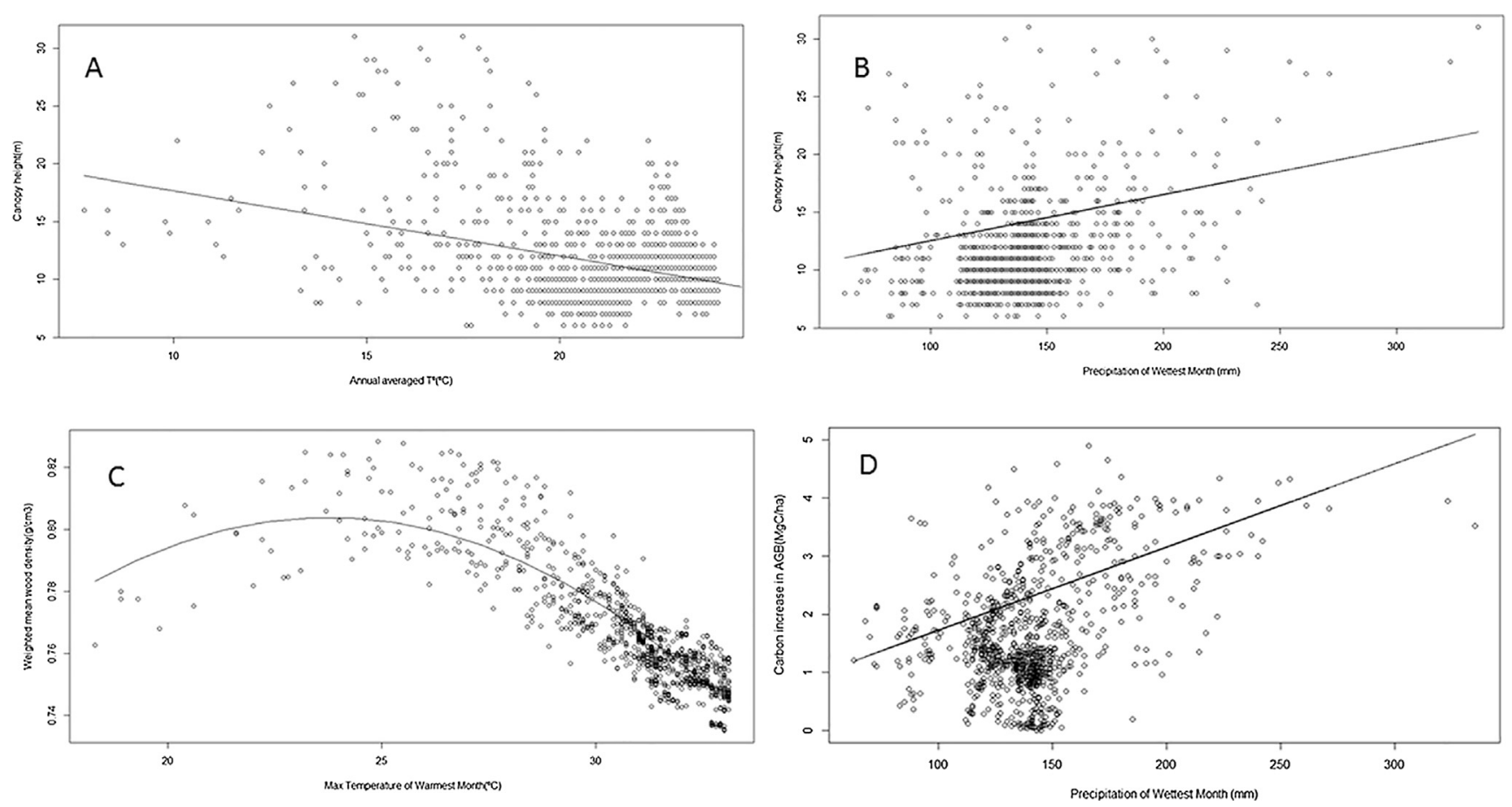

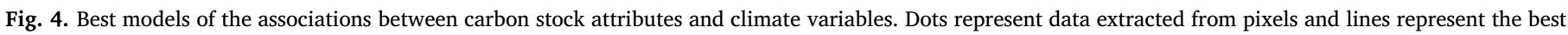

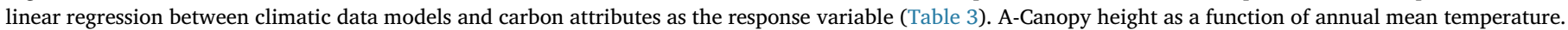

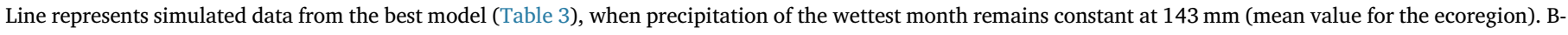

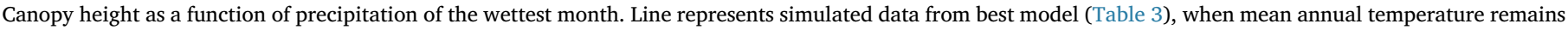

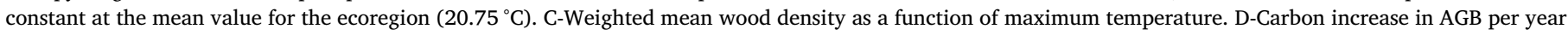
as a function of precipitation of the wettest month.

determination of tree height. Furthermore, a visual comparison of AGB maps from Gasparri and Baldi (2013) and tree height maps reveals that zones with maximum AGB do not match areas of maximum tree height derived in this study. Higher tree heights were found towards the west of the study area, limiting with the Yungas ecoregion (moist forests); and were positively related with precipitation of the wettest month (during summer, the growing season) and negatively related with mean annual temperature. In relation to this, in Brazil, Nogueira et al. (2011) found important differences in the associations between tree diameter and height for individuals of the same species, linked to disturb regime. It is thus worth assessing whether this applies for the Dry Chaco as well, since the associations between tree height, mean temperatures and precipitations suggest a climatic control. Framing the results of our study in the global context, mean tree canopy height values found in the Dry Chaco were far from the tallest ( $40 \mathrm{~m}$ ) (Simard et al., 2011), but maximum values $(32 \mathrm{~m}$ ) imply the existence of tall canopies in these dry forests. The nature of the climatic variables that exerted certain control over tree height In the Dry Chaco suggest that taller forests might need more water during the growing (wetter and warmer) season, but also less temperatures, since both variables are determinant of lower evapotranspiration rates, which are critical for the vegetation in the Chaco (García et al., 2017).

One third of the Dry Chaco forests exhibited fast carbon accumulation rates (with respect to the mean value for the ecoregion). As we expected, taking into account that the Chaco ecoregion is mostly a dry forest, the main control of carbon accumulation was precipitation during the wettest season, (i.e., more precipitations during the wet season accelerate the process of carbon accumulation). The influence of precipitation over productivity found in this study is consistent with that reported by Gasparri and Baldi (2013) for the same area.

For an interpretation of the relationships between carbon increase in AGB and other carbon stock attributes, it is important to keep in mind that the input for the estimation of the amount of carbon stored per year is generated by satellite imagery, and thus, productivity from shrubs and herbs are also included. Today, there is a lack of spatial explicit data of understory vegetation communities for Dry Chaco ecoregion, but a climatic control over productivity is expectable because the areas with higher amount of carbon increase in AGB are mostly more rainy areas with respect to the rest of the ecoregion. In addition, these more productive sectors occur in areas where cattle (the most important human appropriation of net primary productivity, Rueda et al., 2013), is less developed.

The optimum conditions in terms of the persistence and stability of carbon stocks, represented by high weighted mean wood densities, tall tree canopies and fast carbon accumulation at the pixel scale in Dry Chaco forests (i.e., the "best" combination of the three attributes) were found towards the east foothills of the mountains, matching the western limits of the Dry Chaco ecoregion, called "Chaco Serrano" (Torella and Adámoli, 2005). The conjunction of relative low values of maximum temperature during the warmest month (in coincidence with the growing season), and of more precipitations during the same season, derives in more favorable conditions for trees to reach higher canopies, as well as higher wood densities and faster carbon accumulation.

Our results can be useful to forecast future forest attributes based on weather trends analyses, which predict a reduction in the amount of cold days and an increase of warm days and nights, with rainfall tending to concentrate in heavy rainfall events (IPCC, 2014). Combining these weather predictions with our results, it can be expected that the favored tree species turn out to be fast growing species, but of weighted mean low wood densities and low canopy heights. The same attributes would be stimulated by forest degradation because trees species at early stages of succession exhibit the same functional traits (Muller-Landau, 2004). In that sense, Dry Chaco forests would capture less carbon per space unit, making them less perdurable, but with more rapid carbon uptake. Additionally, climate change could make Dry Chaco more favorable for agriculture expansion, and consequently, 
more forests within the area could become threatened (Grau et al., 2005) due to changes in their suitability for land conversion.

Our study emphasizes that, in terms of forest and carbon storage persistence, the cost of nature to build forests, and other proxies of forests stability are useful and informative variables that should be taken into account. Within the Dry Chaco, there is a climatic gradient (Sarmiento, 1972) that promotes differences in forest carbon stocks attributes: northwestern, more humid conditions favoring fast-growing forests with high canopies and high weighted mean wood densities; and southeastern, dry sectors stimulating slow-growing forests, with short canopies and low weighted mean wood densities. These findings highlight that conserving forest carbon stocks can have different implications in terms of forest stability and long-term preservation, according to where they are located.

\section{Acknowledgements}

This work was supported by the Fondo Nacional de Ciencia y Técnica (FONCyT, PICT No. 1693-2006 to H. R. Grau) and by Rufford Small Grants for Conservation (RSG 57.11.08 and RSG 10.12.05). P.Powell, S.Nanni, G.Názaro and D.Loto thank CONICET for their doctoral and post-doctoral fellowships.

\section{Appendix A. Supplementary material}

Supplementary data associated with this article can be found, in the online version, at http://dx.doi.org/10.1016/j.foreco.2018.04.033.

\section{References}

Akaike, H., 1987. Factor analysis and AIC. Psychometrika 52, 317-332.

Baumann, M., Gasparri, I., Piquer-Rodríguez, M., Gavier Pizarro, G., Griffiths, P., Hostert, P., Kuemmerle, T., 2016. Carbon emissions from agricultural expansion and intensification in the Chaco. Global change biology.

Cao, M., Woodward, F.I., 1998. Net primary and ecosystem production and carbon stocks of terrestrial ecosystems and their responses to climate change. Glob. Change Biol. 4 (2), 185-198.

Carlquist, S., 1977. Ecological factors in wood evolution: a floristic approach. Am. J. Botany 887-896.

Chao, K.J., Phillips, O.L., Gloor, E., Monteagudo, A., Torres-Lezama, A., Martínez, R.V., 2008. Growth and wood density predict tree mortality in Amazon forests. J. Ecol. 96 (2), 281-292.

Chave, J., Andalo, C., Brown, S., Cairns, M.A., Chambers, J.Q., Eamus, D., Folster, H., Fromard, F., Higuchi, N., Kira, T., Lescure, J.P., Nelson, B.W., Ogawa, H., Puig, H. Riera, B., Lescure, J.P., 2005. Tree allometry and improved estimation of carbon stocks and balance in tropical forests. Oecologia 145 (1), 87-99.

Chave, J., Muller-Landau, H.C., Baker, T.R., Easdale, T.A., Steege, H.T., Webb, C.O., 2006. Regional and phylogenetic variation of wood density across 2456 neotropical tree species. Ecol. Appl. 16 (6), 2356-2367.

Clark, D.A., Brown, S., Kicklighter, D.W., Chambers, J.Q., Thomlinson, J.R., Ni, J., Holland, E.A., 2001. Net primary production in tropical forests: an evaluation and synthesis of existing field data. Ecol. Appl. 11 (2), 371-384.

Conti, G., Díaz, S., 2013. Plant functional diversity and carbon storage-an empirical test in semi-arid forest ecosystems. J. Ecol. 101 (1), 18-28.

Dahlin, K.M., Asner, G.P., Field, C.B., 2012. Environmental filtering and land-use history drive patterns in biomass accumulation in a mediterranean-type landscape. Ecol. Appl. 22 (1), 104-118.

de Martonne, E., 1926. L'indice d'aridité. Bulletin de l'Association de géographes français $3(9), 3-5$.

Díaz, S., Hector, A., Wardle, D.A., 2009. Biodiversity in forest carbon sequestration initiatives: not just a side benefit. Curr. Opin. Environ. Sustain. 1 (1), 55-60.

Dinerstein, E., Olson, D.M., Graham, D.J., Webster, A.L., Primm, S.A., 1995. Conservation assessment of the terrestrial ecoregions of Latin America and the Caribbean. International Bank for Reconstruction and Development, Washington, DC (United States). Country Dept. I, Latin America and the Caribbean Regional Office.

Feldpausch, T.R., Banin, L., Phillips, O.L., Baker, T.R., Lewis, S.L., Quesada, C.A., Brondizio, E.S., 2010. Height-diameter allometry of tropical forest trees. Biogeosci. Dis. 7, 7727-7793.

García, A.G., Di Bella, C.M., Houspanossian, J., Magliano, P.N., Jobbágy, E.G., Posse, G., Nosetto, M.D., 2017. Patterns and controls of carbon dioxide and water vapor fluxes in a dry forest of central Argentina. Agric. For. Meteorol. 247, 520-532.

Gasparri, N.I., Baldi, G., 2013. Regional patterns and controls of biomass in semiarid woodlands: lessons from the Northern Argentina Dry Chaco. Reg. Environ. Change 13 (6), 1131-1144.

Gasparri, N.I., Grau, H.R., Angonese, J.G., 2013. Linkages between soybean and neotropical deforestation: coupling and transient decoupling dynamics in a multi-decadal analysis. Global Environ. Change 23 (6), 1605-1614.

Gasparri, N.I., Grau, H.R., Manghi, E., 2008. Carbon pools and emissions from deforestation in extra-tropical forests of northern Argentina between 1900 and 2005. Ecosystems 11 (8), 1247-1261.

Grau, H.R., Gasparri, N.I., Aide, T.M., 2005. Agriculture expansion and deforestation in seasonally dry forests of north-west Argentina. Environ. Conserv. 32, 140-148.

Hacke, U.G., Sperry, J.S., Pockman, W.T., Davis, S.D., McCulloh, K.A., 2001. Trends in wood density and structure are linked to prevention of xylem implosion by negative pressure. Oecologia 126 (4), 457-461.

Hansen, M.C., Potapov, P.V., Moore, R., Hancher, M., Turubanova, S.A., Tyukavina, A., Kommareddy, A., 2013. High-resolution global maps of 21st-century forest cover change. Science 342 (6160), 850-853.

Houghton, R.A., 2007. Balancing the global carbon budget. Annu. Rev. Earth Planet. Sci. $35,313-347$.

Houghton, R.A., House, J.I., Pongratz, J., Van der Werf, G.R., DeFries, R.S., Hansen, M.C., Ramankutty, N., 2012. Carbon emissions from land use and land-cover change. Biogeosciences 9 (12), 5125-5142.

INTI-CITEMA, 2003. Instituto Nacional de Tecnología Industrial - Centro de Investigaciones Tecnológicas de la Madera. Listado de densidades secas de maderas. Available on < http://www.inti.gov.ar/citema/densidad_cientifico.pdf $>$. Visited on 4 th april 2017.

IPCC, 2014. Observations: Atmosphere and Surface, Climate Change 2013: The Physical Science Basis. Working Group I Contribution to the Fifth Assessment Report of the Intergovernamental Panel of Climate Change. Cambridge University Press, New York, pp. 1535.

Karger, D.N., Conrad, O., Böhner, J., Kawohl, T., Kreft, H., Soria-Auza, R.W., Zimmermann, N.E., Linder, H.P., Kessler, M., 2017. Climatologies at high resolution for the earth's land surface areas. Sci. Data 4, 170122.

King, D.A., Davies, S.J., Tan, S., Noor, N.S.M.D., 2006. The role of wood density and stem support costs in the growth and mortality of tropical trees. J. Ecol. 94, 670-680.

Kunst, C., 2011. Ecología y uso del fuego en la región chaqueña Argentina: una revisión. Boletín del CIDEU 10, 81-105.

Kunst, C., Ledesma, R., Bravo, S., Albanesi, A., Anriquez, A., Van Meer, H., Godoy, J., 2012. Disrupting woody steady states in the Chaco region (Argentina): responses to combined disturbance treatments. Ecol. Eng. 42, 42-53.

Lefsky, M.A., Cohen, W.B., Harding, D.J., Parker, G.G., Acker, S.A., Gower, S.T., 2002. Lidar remote sensing of above-ground biomass in three biomes. Glob. Ecol. Biogeogr. 11 (5), 393-399.

Meinzer, F.C., 2003. Functional convergence in plant responses to the environment. Oecologia 134 (1), 1-11.

Merow, C., Smith, M.J., Silander, J.A., 2013. A practical guide to MaxEnt for modeling species' distributions: what it does, and why inputs and settings matter. Ecography 36, 1058-1069.

Morello, J.H.y, Rodriguez, A.F., 2009. El chaco sin bosques: la pampa o el desierto del futuro. Orientación gráfica editora. Buenos Aires. 432pp.

Morello, J., Pengue, W., Rodríguez, A., 2005. Etapas de uso de los recursos y desmantelamiento de la biota del Chaco. Fronteras 4 (4).

Muller-Landau, H.C., 2004. Interspecific and inter-site variation in wood specific gravity of tropical trees. Biotropica 36, 20-32.

Nogueira, E.M., Palace, M., Patiño, S., Peh, K.S.H., Raventos, M.T., Reitsma, J.M., Saiz, G., Schrodt, F., Sonké, B., Taedoumg, H.E., Tan, S., White, L., Wöll, H., Lloyd, J., 2011. Height diameter allometry of tropical forest trees. Biogeosciences 8, 1081-1106.

Oliver, C.D., Larson, B.C., 1996. Forest Stand Dynamics, updated edition. John Wiley and sons.

Pan, Y., Birdsey, R.A., Fang, J., Houghton, R., Kauppi, P.E., Kurz, W.A., Ciais, P., 2011. A large and persistent carbon sink in the world's forests. Science 333 (6045), 988-993.

Phillips, S.J., Anderson, R.P., Schapire, R.E., 2006. Maximum entropy modeling of species geographic distributions. Ecol. Model. 190, 231-259.

Portillo-Quintero, C.A., Sánchez-Azofeifa, G.A., 2010. Extent and conservation of tropical dry forests in the Americas. Biol. Conserv. 143 (1), 144-155.

QGIS Development Team, 2017. QGIS Geographic Information System. Open Source Geospatial Foundation Project. < http://qgis.osgeo.org >

R Core Team, 2015. R: A language and environment for statistical. Computing. R Foundation for Statistical Computing, Vienna, Austria. Available on: < http://www. R-project.org/>

Rowe, N., Speck, T., 2005. Plant growth forms: an ecological and evolutionary perspective. New Phytolog. 166 (1), 61-72.

Rueda, C.V., Baldi, G., Verón, S.R., Jobbágy, E.G., 2013. Apropiación humana de la producción primaria en el Chaco Seco. Ecología austral 23 (1), 44-54.

Saatchi, S.S., Harris, N.L., Brown, S., Lefsky, M., Mitchard, E.T., Salas, W., Petrova, S. 2011. Benchmark map of forest carbon stocks in tropical regions across three continents. Proc. Natl. Acad. Sci. 108 (24), 9899-9904.

Sarmiento, G., 1972. Ecological and floristic convergences between seasonal plant formations of tropical and subtropical South America. J. Ecol. 60, 367-410.

Simard, M., Pinto, N., Fisher, J., Baccini, A., 2011. Mapping forest canopy height globally with spaceborne lidar. J. Geophys. Res. 116, 12.

Torrella, S.A., Adámoli, J., 2005. Situación ambiental de la ecorregión del Chaco Seco. In: Brown, A., Martinez Ortiz, U., Acerbi, M., Corcuera, J., (eds). La situación ambiental Argentina 2005. Fundación Vida Silvestre Argentina. Buenos Aires. 587pp.

Torres, R., Gasparri, N.I., Blendinger, P.G., Grau, H.R., 2014. Land-use and land-cover effects on regional biodiversity distribution in a subtropical dry forest: a hierarchical integrative multi-taxa study. Reg. Environ. Change 14 (4), 1549-1561.

Xie, Y., Sha, Z., Yu, M., 2008. Remote sensing imagery in vegetation mapping: a review. J. Plant Ecol. 1 (1), 9-23.

Yackulic, C.B., Chandler, R., Zipkin, E.F., Royle, J.A., Nichols, J.D., Grant, E.H.C., Veran, S., 2013. Presence-only modelling using MAXENT: when can we trust the inferences? Methods Ecol. Evol. 4, 236-243.

Zhao, M., Running, S.W., Nemani, R.R., 2006. Sensitivity of Moderate Resolution Imaging Spectroradiometer (MODIS) terrestrial primary production to the accuracy of meteorological reanalyzes. J. Geophys. Res. Biogeosci. 111. 